\title{
PENAMBAHAN L - ARGININ DALAM PENGENCER TRIS KUNING TELUR SETELAH EKUILIBRASI 2 JAM TERHADAP MOTILITAS DAN MEMBRAN PLASMA UTUH SPERMATOZOA DOMBA SAPUDI
}

\section{THE ADDITION OF L - ARGININE IN TRIS EGG YOLK DILUENT AFTER TWO HOUR EQUILIBRATION TIME TO THE MOTILITY AND PLASMA MEMBRANE INTACT OF SPERMATOZOA SAPUDI SHEEP}

\author{
Hastini Suryaningsih $^{1)}$, Emy Koestanty Sabdoningrum ${ }^{2)}$, Suherni Susilowati ${ }^{3)}$, \\ Trilas Sardjito ${ }^{4)}$, Wurlina ${ }^{5)}$, Tita Damayanti ${ }^{6)}$ \\ ${ }^{1)}$ Student, ${ }^{2)}$ Veterinary Animal Husbandry, ${ }^{3,4,5,6)}$ Veterinary Reproduction Department \\ Faculty of Veterinary Medicine, Airlangga University \\ astisuryaningsih@ymail.com
}

\begin{abstract}
This research was aimed to determine the addition of L-arginine on motility and sperm plasma membrane of Sapudi sheep after two hour equilibration time in egg yolk tris diluent. This research used fresh samples of sheep Sapudi semen collected by artificial vagina, then were devided into 4 treatments and 6 replications. Analysis of the data using Analysis of Variance (ANOVA) then proceed to the Duncan Test to determine significant differences between treatments. The first treatment $\mathrm{P} 0$ was no $\mathrm{L}-$ Arginine added as control. P1 was treated with $0,004 \mathrm{M} \mathrm{L}$ - Arginine. P2 was treated with $0,005 \mathrm{M} \mathrm{L}$ - Arginine, P3 was treated with $0,006 \mathrm{M} \mathrm{L}$ - Arginine. Result of two hour equilibration time for the sperm motility showed: (P0) 46,67 $\pm 5,16$, (P1) 49,16 $6^{\mathrm{ab}} \pm 5,84$, (P2) 55,00 ${ }^{\mathrm{bc}} \pm 7,74$, (P3) $58,33^{\mathrm{c}} \pm 6,83$. Result of two hour equilibration time for the sperm plasm membrane were: (P0) $39,33^{\mathrm{a}} \pm 4,92$, (P1) 43,33 ${ }^{\mathrm{ab}} \pm$ 4,22 , (P2) $46,50^{\mathrm{bc}} \pm 3,44$, (P3) $50,83^{\mathrm{c}} \pm 3,48$. The addition of L-arginine with a concentration as much as $0.006 \mathrm{M}$, shows the highest result in sperm motility and sperm plasm membrane intact of Sapudi semen.
\end{abstract}

Keywords : Sapudi sheep, spermatozoa, L - arginine, Motility, plasma membrane intact

\section{Pendahuluan}

domba memiliki peranan yang cukup signifikan sebagai penyedia daging dalam mendukung upaya pemerintah untuk meningkatkan konsumsi protein hewani masyarakat. Permasalahan pengembangan peternakan domba adalah belum tersedianya bibit ternak berkualitas dalam jumlah yang cukup mudah diperoleh dan dijangkau serta terjamin konti-nuitasnya, kekurangan bibit unggul, penurunan produksi bibit ternak dan daya saing usaha perbibitan lokal yang rendah (Ditjennak, 2009).

Salah satu usaha guna mengatasi masalah tersebut adalah menerapkan teknologi repro-duksi inseminasi buatan (IB). IB adalah pe-nempatan semen pada saluran reproduksi secara buatan. Semen yang ditempatkan dapat berupa semen beku maupun semen segar. Melalui teknologi IB, potensi domba pejantan unggul dapat dioptimalkan karena semen yang diperoleh dari pejantan unggul dapat diolah sehingga lebih banyak jumlah domba betina yang dapat dikawinkan (Herdis et al., 2005)

Salah satu faktor yang menyebabkan rendahnya angka kebuntingan adalah kurang baiknya kualitas semen yang digunakan. Selain dari kualitas semen, proses pembekuan juga dapat menurunkan kualitas semen. Pada proses ekuilibrasi terjadinya suatu peroses yang disebut cengkaman dingin (cold shock) yang dapat merusak membran plasma sel dan berakibat kematian spermatozoa (Rizal et al., 2006). Berbagai usaha untuk menjaga kualitas semen dapat dilakukan dengan menambahkan berbagai zat ke dalam pengencer. Pengencer yang baik harus harus dapat melindungi spermatozoa terhadap pendinginan yang cepat selama proses penyimpanan (Bearden dan Fuquay, 1997).

Salah satu zat yang dapat ditambahkan ke dalam pengencer semen beku adalah LArginin. Guna penambahan L-Arginin pada 
semen beku adalah menghambat aktifitas radikal bebas. Nitric Oxide yang terdapat dalam L-Arginin bersifat antioksidan sehingga dapat menginaktivasi superoksida yang dihasilkan oleh spermatozoa selama proses konsumsi oksigen. Keberadaan superoksida dalam jumlah berlebih menyebabkan peroksidade pada membrane fosfolipid spermatozoa se-hingga menimbulkan kerusakan secara fung-sional. Peroksidase lipid pada membrane spermatozoa yang dicegah oleh asam amino arginin dengan meningkatkan produksi Nitric oxide (Srivastava et al., 2006).

\section{Materi dan Metode \\ Waktu dan Tempat Penelitian}

Penelitian dilaksanakan di Laboratorium Inseminasi Buatan Departemen Reproduksi Fakultas Kedokteran Hewan Universitas Airlangga Surabaya untuk pembuatan bahan pengencer semen domba. Ambil semen domba dilakukan di Kandang Domba Fakultas Kedokteran Hewan Universitas Airlangga Surabaya. Penelitian ini dilaksanakan pada bulan Agustus September 2016

\section{Bahan dan Materi Penelitian}

Bahan yang digunakan dalam penelitian ini adalah : semen dari seekor domba jantan, pengencer tris kuning telur, LArginin A5006 (Singapore Science Park Road II ), Air hangat, Larutan HOS test (Hypo Osmotic Swelling) yang digunakan dalam pemeriksaan keutuhan membran plasma spermatozoa, Eosin Negrosin, gliserol $10 \%$, Nacl.

Alat yang digunakan untuk pengenceran semen dan penambahan L-arginin, meliputi: gelas batang pengaduk, tabung penampung semen, beaker glass, kain kasa, kertas saring, gelas ukur, dan lemari pendingin.

Alat yang digunakan untuk penampungan semen yaitu dengan memakai vagina buatan. Alat yang digunakan untuk pemeriksaan mikroskopis, meliputi : gelas objek, gelas penutup, batang pengaduk, mikroskop, dan spektrofotometer. Alat yang digunakan untuk pemeriksaan makroskopis, meliputi : tabung berskala dan $\mathrm{pH}$ meter atau kertas lakmus.

Alat yang digunakan untuk uji Hypo Osmotic Swelling Test, meliputi : gelas objek, gelas penutup, pipet tetes, dan mikroskop.

\section{Metode Penelitian \\ Penampungan Semen}

Penampungan semen domba dalam penelitian ini menggunakan vagina buatan yang dilakukan sekali dalam satu minggu.

\section{Evaluasi Semen Sebelum Perlakuan}

Semen yang digunakan harus memiliki kualitas yang baik. Untuk mengetahui kualitas semen, dapat dilakukan dengan pemeriksaan makroskopis dan mikroskopis. Pemeriksaan makroskopis meliputi pemeriksaan volume, konsistensi, warna, bau dan $\mathrm{pH}$. Sedangkan pemeriksaan mikroskopis meliputi gerak massa dan gerak individu, konsentrasi, persentase spermatozoa yang hidup, mati dan abnormal.

\section{Pengenceran Semen}

Dalam penelitian ini ada empat perlakuan yang ditambahkan pada pengencer Tris Kuning Telur yaitu :

1. Perlakuan kontrol $(\mathrm{P} 0)$ : semen + Tris Kuning Telur

2. Perlakuan $1(\mathrm{P} 1)$ : semen + pengencer Tris Kuning Telur $+\mathrm{L}-$ Arginin 0,004 $\mathrm{M} / \mathrm{ml}$

3. Perlakuan $2(\mathrm{P} 2)$ : semen + pengencer Tris Kuning Telur $+\mathrm{L}-$ Arginin 0,005 $\mathrm{M} / \mathrm{ml}$

4. Perlakuan $3(\mathrm{P} 3)$ : semen + pengencer Tris Kuning Telur $+\mathrm{L}-$ Arginin 0,006 $\mathrm{M} / \mathrm{ml}$

\section{Penambahan $\mathbf{L}$ - Arginin}

$\mathrm{L}$ - arginin ditambahkan setelah proses pencampuran semen dengan pengencer Tris Kuning Telur. Dengan Konsentrasi L Arginin yang digunakan pada penelitian sebelumnya antara lain $0,004 \mathrm{M} / \mathrm{ml}, 0,005$ $\mathrm{M} / \mathrm{ml}$, dan $0,006 \mathrm{M} / \mathrm{ml}$ bahan pengencer (Ardilla, M. 2016).

\section{Pemeriksaan Setelah Di Ekuilibrasi}

Pemeriksaan stelah di ekuilibrasi meliputi pemeriksaan motilitas dan membran plasma utuh. Pemeriksaan membran plasma utuh spermatozoa dilakukan dengan menggunakan uji pembengkakan hipoosmotik atau Hypoosmotic Swelling Test (HOS). Pemeriksaan motilitas dilakukan dengan larutan Nacl fisiologis. 
Tabel 1. Rerata dan Standard Deviasi Motilitas Spermatozoa Domba Sapudi Setelah Ekuilibrasi $2 \mathrm{Jam}$

\begin{tabular}{ccc}
\hline Perlakuan & Ulangan & Motilitas \% (X \pm SD $)$ \\
\hline P0 & 6 & $46,67^{\mathrm{a}} \pm 5,16$ \\
P1 & 6 & $49,16^{\mathrm{a}} \pm 5,84$ \\
P2 & 6 & $55,00^{\mathrm{bc}} \pm 7,74$ \\
P3 & 6 & $58,33^{\mathrm{c}} \pm 6,83$ \\
\hline
\end{tabular}

Superskrip yang berbeda pada kolom yang sama menunjukkan adanya perbedaan yang nyata $(\mathrm{p}<0,05)$

\section{Hasil dan Pembahasan}

Persentase Motilitas Spermatozoa Domba Sapudi

Hasil penelitian penambahan L-Arginin ke dalam pengencer tris kuning telur terhadap motilitas spermatozoa dengan berbagai konsentrasi menunjukan angka rata rata dan standar deviasi berturut - turut adalah P0 sebesar 46,67 $\pm 5,16$; P1 sebesar

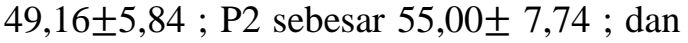
P3 sebesar 58,33 \pm 6,83 yang dapat dilihat pada tabel 4.3.

Hasil uji ANOVA terhadap penambahan L-Arginin ke dalam pengencer tris kuning telur menunjukkan bahwa adanya perbedaan yang nyata $(p \leq 0,05)$ terhadap motilitas spermatoza domba sapudi setelah ekuilibrasi 2 jam sehingga dilanjutkan dengan uji Duncan untuk mengetahui konsentrasi yang terbaik terhadap persentase motilitas spermatozoa. Hasil uji Duncan menunjukkan bahwa $\mathrm{P} 0$ berbeda nyata $(\mathrm{p} \leq 0,05)$ dengan $\mathrm{P} 2$ dan $\mathrm{P} 3$. Begitu juga antara P2 menunjukkan hasil yang berbeda nyata $(p \leq 0,05)$ dengan $\mathrm{P} 1$ maupun $\mathrm{P} 3$. Hasil penelitian ini menunjukkan terjadinya peningkatan motilitas spermatozoa. Penambahan L-Arginin $0,006 \mathrm{M} / \mathrm{ml}$ dalam pengencer tris kuning telur menghasilkan angka tertinggi yaitu $58,33 \%$. Patel et al.1998 menyatakan bahwa keberadaan Larginin dalam konsentrasi rendah tidak hanya meningkatkan metabolisme dan spermatogenesis, tetapi juga meningkatkan sintesis Adenosin Trifosfat (ATP), yang merupakan komponen esensial kaya energi untuk motilitas sperma.

L-Arginin berperan penting untuk meningkatkan dan mempertahankan motilitas spermatozoa (C.O'Flaherty., 2004) dan LArginin berperan dalam pertahanan imunitas seluler serta memberikan perlindungan terhadap membran peroksidasi lipid dengan meng-hasilkan Nitric Oxide (NO) melalui enzim Nitric Oxide Synthase (NOS) (Srivasta et al., 2006). Dalam studi in vitro menunjukkan bahwa nitrix oxide NO dapat meningkatkan motilitas sperma sedangkan konsentrasi tinggi nitric oxide NO dapat menurunkan motilitas sperma (Rosselli et al. 1998 ; Herrero et al .2003). Apabia membran plasma rusak maka proses metabolisme akan terganggu. Sintesa ATP tidak berjalan dengan normal dan berakibat fatal bagi spermatozoa yaitu menurunnya motilitas maupun daya tahan sperma itu sendiri (Sukmawati dkk 2014).

\section{Persentase Membran Plasma Utuh Spermatozoa Domba Sapudi}

Hasil penelitian penambahan L-Arginin ke dalam pengencer tris kuning telur terhadap membran plasma utuh dengan berbagai konsentrasi menunjukkan angka rata - rata dan standar deviasi berturut turut adalah P0 sebesar 39,3 \pm 4,92; P1 sebesar 43,33 $\pm 4,22 ; \quad P 2$ sebesar

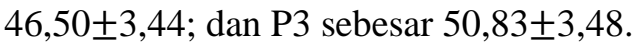

Berdasarkan tabel 4.3, rerata membran plasma utuh spermatozoa domba Sapudi setelah ekuilibrasi 2 Jam dapat dilihat dalam Grafik 4.3.

Hasil Uji ANOVA terhadap penambahan L-Arginin kedalam pengencer tris kuning telur menunjukkan bahwa adanya perbedaan yang nyata $(\mathrm{p} \leq 0,05)$ terhadap membran plasma utuh spermatozoa domba sapudi setelah ekuilibrasi 2 jam sehingga dilanjutkan dengan uji Duncan untuk mengetahui konsentrasi yang terbaik terhadap persentase membran plasma utuh spermatozoa. Hasil uji Duncan menunjukkan bahwa P0 berbeda nyata $(\mathrm{p} \leq 0,05)$ dengan $\mathrm{P} 1, \mathrm{P} 2$ dan $\mathrm{P} 3$. 
Tabel 2. Rerata dan Standard Deviasi Membran Plasma Utuh Spermatozoa Domba Sapudi Setelah Ekuilibrasi 2 Jam

\begin{tabular}{ccc}
\hline Perlakuan & Ulangan & Membran Plasma Utuh \% (X \pm SD ) \\
\hline P0 & 6 & $39,33^{\mathrm{a}} \pm 4,92$ \\
P1 & 6 & $43,33^{\mathrm{ab}} \pm 4,22$ \\
P2 & 6 & $46,50^{\mathrm{bc}} \pm 3,44$ \\
P3 & 6 & $50,83^{\mathrm{c}} \pm 3,48$ \\
\hline
\end{tabular}

Superskrip yang berbeda pada kolom yang sama menunjukkan adanya perbedaan yang nyata $(\mathrm{p}<0,05)$

Penambahan L-Arginin dalam pengencer tris kuning telur dengan konsentrasi 0,006 $\mathrm{M} / \mathrm{ml}$ menunjukkan hasil tertinggi adalah 50,83 .

Keutuhan membran plasma merupakan integritas spermatozoa yang sangat berperan dalam proses fertilisasi untuk keberhasilan IB (Herdis, dkk. 1999), mengingat fungsi membran tersebut dapat mengatur keluar masuknya zat-zat makanan, ion-ion yang diperlukan dalam proses metabolisme serta menjaga keseimbangan elektrolit intra dan ekstraseluler. Menurut Feradis (2010) MPU spermatozoa ditandai dengan adanya pembengkakan dan melingkar pada ujung ekor sperma, ekor yang pendek dan tebal atau pembengkakan pada sebagian atau seluruh bagian yang dibentuk oleh ekor spermatozoa, sedangkan untuk spermatozoa yang rusak ditandai dengan ekor yang lurus. Bentuk dan ciri kerusakan spermatozoa akibat peroksidasi lipid adalah menurunnya motilitas ,kerusakan enzim intraseluler dan kerusakan struktur membran plasma (Guthrie and Welch., 2012).

Keutuhan membran plasma sangat diperlukan oleh spermatozoa, karena kerusakan membran plasma akan berpengaruh terhadap proses metabolisme dan berhubungan dengan motilitas serta daya hidup spermatozoa yang dihasilkan. Metabolisme sel akan berlangsung baik jika membran plasma sel berada dalam keadaan yang utuh, sehingga mampu dengan baik mengatur lalu lintas masuk dan keluar dari sel semua substrat dan elektrolit yang dibutuhkan dalam proses metabolisme (Surachman dkk., 2009). Penurunan kualitas spermatozoa selama penyimpanan, baik persentase motilitas progresif maupun keutuhan membran plasma terjadi akibat banyaknya spermatozoa yang mati dan menjadi toksik terhadap spermatozoa lain yang masih hidup, sehingga secara umum kualitasnya menjadi menurun. toksik yang berasal dari spermatozoa yang telah mati maupun yang pengencer yang telah mengalami oksidasi akibat penyimpanan dapat menyebabkan tingginya kadar radikal bebas yang dapat merusak keutuhan mem-bran plasma spermatozoa.

Mekanisme L-Arginin untuk menjaga kualitas spermatozoa terutama memberikan perlindungan terhadap membran dari lipid peroksidasi dengan menghasilkan NO (Nitric Oxide). NO (Nitric Oxide) adalah penggerak utama dari adenilat guanylate larut dalam spermatozoa, dan jumlah yang signifikan monofosfat guanosin siklik sebagai signaling jalur NO menginduksi reaksi akrosom, sperma kemotaksis, dan interaksi sperma-telur (Revelli et al. 2001, 2002). Mekanisme ini sesuai dengan mekanisme antioksidan dalam melindungi sel dari radikal bebas, Nitric Oxide dapat menginaktivasi superoksida yang diha-silkan oleh spermatozoa selama proses konsumsi oksigen. Keberadaan superoksida dalam jumlah berlebih menyebabkan peroksidade pada membrane fosfolipid spermatozoa sehingga menimbulkan kerusakan secara fungsional. Peroksidase lipid pada membrane spermatozoa yang dicegah oleh asam amino arginin dengan meningkatkan produksi Nitric oxide (Srivastava et al., 2006).

Roca (1997) menyatakan bahwa Tris Kuning Telur merupakaan pengencer yang baik untuk proses pembekuan semen jika ditinjau dari viabilitas dan daya fertilitasnya. Penelitian yang dilakukan D'Alessandro et al. (2001) pada domba menunjukkan pengencer Tris Kuning Telur dapat mempertahankan daya hidup dan menurunkan tingkat kerusakan akrososm lebih baik dari pada susu laktosa kuning telur. 


\section{Kesimpulan}

1. Terdapat peningkatan persentase motilitas spermatozoa domba Sapudi setelah Penambahan L-Arginin dengan konsentrasi $0,005 \mathrm{M} / \mathrm{ml}$ dan $0,006 \mathrm{M} / \mathrm{ml}$ diluter

2. Terdapat peningkatan persentase membran plasma utuh spermatozoa domba sapudi setelah Penambahan L-Arginin $0,005 \mathrm{M} / \mathrm{ml}$ dan $0,006 \mathrm{M} / \mathrm{ml}$ diluter

\section{Daftar Pustaka}

Bearden, H.J. and J.W. Fuquay. 1997. Applied Animal Reproduction, 4thed.

C.O'Flaherty, P. Rodriguez ,S. Srivastava .2004. L-Arginine promotes capatitation and acrosome reaction in cryopreserved bovine spermatozoa. Biochimica et Biophysica Acta 1674 (2004) 215-221

D'Alessandro A.G.,Martemucci G., Colonna M.A., Belitti A. 2001. Post-thaw sur-vival of ram spermatozoa and fertility after insemination as effected by prefreezing sperm concentration and exten-der composition. Theriogenology 55 (5) : 1159-1170.

Direktorat Jenderal Peternakan, Departemen Pertanian, Jakarta.

Ditjennak, 2009. Rencana Strategis Direktorat Jenderal Peternakan 2010-2014.

Feradis. 2010. Bioteknologi Reproduksi Pada Ternak. Alfabeta. Bandung. 18,53,74-75,84-85

Guthrie HD,Welch GR. 2012. Effects of reactive oxygen species on sperm function. SciVerse Science Direct. Theriogenol.78:1700 - 1708.

Herdis,M.Surachman,I.Kusuma dan E.R.Suhana. 1999. Peningkatan efisiensi reproduksi sapi melalui penerapan teknologi penyerentakan berahi Wartazoa. 9(1): $1-6$.

Herdis. 2005. Optimalisasi Inseminasi Buatan Melalui Aplikasi Teknologi Laserpunktur pada Domba Garut (Ovis aries). Disertasi. Bogor: Institut Pertanian Bogor.

Herrero MB, de Lamirande E, Gagnon C (2003) Nitric oxide is a signaling molecule in spermatozoa. Curr Pharm Des 9:419-425. doi:10.2174/1381612033391720

Patel, A.B., Srivastava, S., Phadke, R.S., Govil, G., 1998, Arginin Activates Glycolysis of Goat Epididymal Spermatozoa: an NMR study, Biophys J, 75: $1522-1528$.

Revelli A, Costamagna C, Moffa F, Aldieri E, Ochetti S, Bosia A, Massobrio M, Lindblom B, Ghigo D (2001) Signaling pathway of nitric oxideinduced acro-some reaction in human spermatozoa. Biol Reprod 64:17081712. doi:10.1095/biolreprod64.6.1708

Revelli A, Ghigo D, Moffa F, Massobrio M, Tur-Kaspa I (2002) Guanylate cyclase activity and sperm function. Endocr Rev 23:484-494. doi:10.1210/er.2001-0020

Rizal M. 2006. Fertilitas semen beku hasil ejakulasi dan spermatozoa beku asal cauda epididimis domba garut. J Sain Veteriner 24: 49-57.

Roca, J. 1997. Viability and fertility of unwashed Murciano Granadina goat spermatozoa diluted in Tris egg yolk extender and stored at $5^{\circ} \mathrm{C}$. Small Ruminant Research 25:147-153.

Rosselli M, Keller RJ, Dubey RK (1998) Role of nitric oxide in the biology, physiology and pathophysiology of reproduction. Hum Reprod Updat 4:3-24. doi:10.1093/humupd/4.1.3

Srivastava S,Desai P,Coutinho E, Govil G (2006) Protective effect of L Arginine against lipid peroxidation in goat epididymal spermatozoa.Physiol Chem Phys Med NMR 32:127 - 135

Surachman, M., Herdis, Yulnawati, M. Rizal, dan H.Maheshwari. 2009. Kualitas Semen Cair Asal Epididimis Kerbau Belang dalam Bahan Pengencer An-dromed yang Mendapat Penambahan Sukrosa. Media Peternakan: 32(2). 